\title{
Correlates of Premarital Relationships Among Unmarried Youth in Pune District, Maharashtra, India
}

\author{
ByMallika \\ Alexander, \\ Laila Garda, \\ Savita Kanade, \\ Shireen Jejeebhoy \\ and Bela Ganatra \\ Mallika Alexander is \\ research scientist, \\ Laila Garda is \\ research scientist and \\ Savita Kanade is \\ social scientist-all \\ with the KEM \\ Hospital Research \\ Centre, Pune, India. \\ Shireen Jejeebhoy is \\ senior associate, \\ Population Council, \\ New Delhi, India. \\ Bela Ganatra is senior \\ research and policy \\ advisor for Asia, Ipas, \\ Pune, Jndia.
}

\begin{abstract}
CONTEXT: Although premarital partnerships - whether or not they involve sex — are widely discouraged in India, some youth do form such partnerships. It is important to know more about the nature of and the factors associated with these relationships.
\end{abstract}

METHODS: Data are drawn from a community-based study of 15-24-year-olds in urban slum and rural settings in Pune District, Maharashtra. Multivariate analyses were conducted to identify associations between youths' individual, peer and family factors and their experience of romantic relationships and physical intimacy, including intercourse.

RESULTS: Among young men, 17-24\% had had a romantic relationship, 20-26\% had engaged in some form of physical intimacy and 16-18\% had had sex; the proportions among young women were 5-8\%, 4-6\% and 1-2\%, respectively. Exposure to alcohol, drugs or pornographic films and having more frequent interaction with peers were positively associated with romantic and sexual relationships for both young women and young men. Educational attainment was negatively associated with both types of relationships for young women, but only with sexual relationships for young men. Closeness to parents was negatively associated with relationships only for young women. Young women whose father beat their mother were more likely than other young women to form romantic partnerships, and those beaten by their family had an elevated risk of entering romantic and sexual partnerships. Youth who reported strict parental supervision were no less likely than others to enter relationships.

CONCLUSIONS: Program interventions should ensure that youth are fully informed and equipped to make safe choices and negotiate wanted outcomes, while positively influencing their peer networks; encourage closer interaction between parents and children; and be tailored to the different circumstances and experiences of young women and men. International Family Planning Perspectives, 2007, 33(4):150-159
Premarital partnerships among youth, including those not involving sexual intercourse, are widely discouraged in India; yet, despite strict sanctions, including parental violence, loss of reputation and swiftly arranged marriages to someone other than the romantic partner, up to $10 \%$ of young women and $15-30 \%$ of young men form such partnerships. ${ }^{1-6} \mathrm{~A}$ review of the literature suggests that little is known about the nature of these relationships, ${ }^{1}$ such as whether they are romantic or casual, or how individual, family, peer and community factors are associated with partnership formation.

This article aims to address these gaps in evidence by describing the romantic and sexual relationships of unmarried youth in one slum and one rural setting in Pune, India, and by identifying factors associated with their formation. The findings are intended to inform program planners about the range of romantic and sexual relationships experienced by young women and men, and thereby contribute to the design of evidence-based interventions to reduce risky behaviors in this population.

\section{Background}

Evidence on factors associated with sexual relations among unmarried youth is sparse. Indeed, a global review concludes that the identification of factors that inhibit or fa- cilitate safe sexual behavior among young women and men is an urgent issue for research. ${ }^{7}$

The research that is available, which comes largely from developed countries, has identified a number of factors associated with risky or safe premarital sexual relations. Key factors relating to the individual that appear protective against unsafe sex include skills in problem solving, decision making and negotiation, and feelings of self-worth, ${ }^{8-11}$ on the other hand, substance use and exposure to pornographic materials have been found to be inversely associated with safe sex. ${ }^{10,12}$

The literature suggests, however, that although individual attributes are important in preventing negative outcomes, a supportive environment-particularly a young person's family, school and peer network-is equally important. ${ }^{8}$ Youths' behaviors are also known to be influenced by peerrelated factors, such as the norms and behaviors of their friends. ${ }^{9}, 10,12,13$ Although peer norms and peer pressure may be important factors underlying early sexual initiation, ${ }^{9,10}$ it is also likely that larger peer groups and higher levels of social interaction lead to greater opportunities for youth to form romantic partnerships. Finally, among family and household factors, poverty clearly exacerbates the risks that youth face; it constrains their ability to engage in safe sex- 
ual relationships and is associated with adverse sexual and reproductive health outcomes. ${ }^{14}$ Key family factors observed to be protective against unsafe premarital sex include living with both parents, having a father present in the household, appropriate monitoring and supervision, parent-child communication and connection, and the absence of family violence. . $^{9,10,13-17}$

In India, studies that address correlates are rare. Findings from a study of college students in Mumbai, for example, found that individual factors-notably access to resources, attitudes favorable to premarital sex and exposure to pornographic materials-were associated with premarital sex. ${ }^{4}$ At the family level, individuals who perceived their family environment to be restrictive or uncomfortable were more likely than others to report sexual experience. Findings from a qualitative study of youth in a Delhi slum setting describe how, despite strict parental supervision, girls found ways of forming romantic friendships and engaging in sexual relations. ${ }^{2}$ Finally, frequency of peer interaction was positively associated with sexual experience. ${ }^{4}$

Although the existing research has focused on the correlates of premarital sexual behavior among youth, we hypothesize that in a highly restricted social setting such as India's, any partnership-regardless of whether it involves sex-may be influenced by a similar set of factors. Our conceptual framework, which is derived from the available literature, postulates that whether a romantic partnership is formed and whether that partnership involves physical intimacy or sex depends on three sets of factors: individual attributes, such as schooling, economic activity status and agency; familial attributes, such as parent-child communication, parental restrictiveness and family violence; and peer attributes, including frequency and depth of peer interaction and youth norms.

\section{Study Setting}

The study was conducted in two sites in Pune District of Maharashtra State. Maharashtra is highly developed and provides youth with a range of educational and employment opportunities. ${ }^{18}$ Educational attainment levels are considerably higher in Maharashtra than in India overall, and gender differences in enrollment are considerably narrower. In 1998-1999, for example, 9\% of 15-19-year-old males could not read or write, compared with $18 \%$ of females in that age-group; among 15-17-year-olds, $65 \%$ of males attended school, compared with $54 \%$ of females. ${ }^{19}$ Furthermore, marriage occurs during adolescence for large proportions of young women but for few young men: As recently as 2005-2006, 40\% of women aged 18-29 were married by age 18; in comparison, just $13 \%$ of men aged 21-29 were married by age $21 .{ }^{20}$

Pune District has a population of 7.2 million and is one of the most economically developed of Maharashtra's 35 districts. ${ }^{18}$ It is also one of six districts in the state with high HIV prevalence. ${ }^{21}$ Pune is close to the state's capital, Mumbai; perhaps for that reason, its youth have greater access to education, employment opportunities, modern consumer goods, new ideas and modern lifestyles than youth elsewhere in the state. ${ }^{18,22}$

Given the sensitivity of our topic, we were concerned about potential community hostility and difficulty in gaining access to youth, especially adolescent females. Thus, we opted to locate the study in settings in which health and development agencies already enjoyed considerable rapport with and insight into the communities they served. In 2001, Mawal Subdistrict had a rural population of 305,083 spread over 180 villages; half of these villages made up the rural setting for our study. The social and demographic profile of rural Mawal was fairly typical of the district more generally: For instance, the scheduled caste and tribal populations comprised 15\% each of the district and subdistrict populations, respectively; and female literacy rates were $46 \%$ and $52 \%$ in rural Mawal and rural Pune, respectively. Pune City-the urban study setting-has a population of 2.5 million people, of whom some 530,000 are estimated to reside in slums. ${ }^{22,23}$ Our study was conducted in one large slum setting.

The two nongovernmental organizations in whose sites the study was undertaken offered general health and development services, but did not include specific services for sexual and reproductive health of youth.*

\section{METHODS \\ Study Design}

The study consisted of three phases: a presurvey qualitative phase; a survey of married and unmarried young women and men; and postsurvey in-depth interviews with selected survey respondents. ${ }^{24,25}$ The presurvey qualitative phase-conducted in 2003-comprised 13 focus group discussions with youth, ${ }^{21}$ interviews with local health care providers, teachers and other individuals familiar with youth; and 13 in-depth interviews with selected youth. This phase was intended to inform the development of the survey instrument and gain insight into the romantic and sexual experiences of youth. Postsurvey in-depth interviews, 149 in all, were conducted with married and unmarried youth reporting various romantic and sexual experiences in the survey. These interviews were intended to enable researchers to better understand the nature of these relationships. In this article, we restrict our discussion to unmarried participants and focus largely on survey findings, using textual data to provide insight into survey findings.

In light of the expected gender differences in sexual experience, the possible refusal and nonresponse to sensitive questions related to sexual experiences and a probable design effect that could have biased the randomness of the sample, our sampling strategy called for a sample size of 2,150 and 950 unmarried young women and men, respectively, from each site. An initial house-listing exercise identified all households in each site with youth aged 15-24: A total of 21,179 rural households and 19,336 urban slum

*The rural site is served by KEM Hospital; the NGO CASP works in the urban slum. The mere presence of these activities in these settings may have distinguished these settings from others in the district at large. 
households, containing populations of 99,237 and 96,680 people, respectively, were enumerated. We prepared lists of all unmarried and married youth. These lists contained 3,646 females and 7,352 males in the rural setting and 4,169 and 8,191 , respectively, in the urban setting. Samples were drawn randomly from each list; if a household contained more than one eligible male, only one was selected at random; if more than one eligible female was identified, likewise, only one was selected at random. More than $80 \%$ of each of the four sample targets of unmarried females and males in rural and urban slum settings was reached.

Conducted in 2004-2005, the survey used closed-ended questions to explore in detail the romantic partnerships in which young people engage. Questions were posed in terminology identified in the presurvey qualitative phase as language used by young people. Efforts were made to ensure that the interviews were conducted in private and in locations that were convenient for the respondents; interviews typically lasted an hour.

The reliability of survey self-reports on sexual experience is a matter of concern, and we had no way of assessing internal or external consistency of data. ${ }^{26}$ Thus, we undertook several measures to reduce potential underreporting and made special efforts to build rapport between the study communities and the study team. For instance, emphasis was placed on the selection and training of interviewers: Interviewers, who were generally in their 20s, underwent an intensive three-week training during which they not only became familiar with the questionnaire and with sexual and reproductive matters relating to youth, but also learned how to build rapport with their respondents and overcome any discomfort they had about discussing sexual matters.

The survey instrument was informed by findings from the presurvey qualitative phase as well as other instruments relating to youth behaviors, ${ }^{27-31}$ and underwent several revisions following pretesting. Questions on the nature of relationships proceeded in a gradual way from less to more sensitive; experiences (e.g., holding hands, kissing and sex) in romantic relationships were asked separately from other experiences-sex that was forced, with a same-sex partner, or, for young men, with a sex worker or married woman. At the conclusion of the interview, respondents were asked a single question: "Have you ever had sex with anyone?" The respondents were asked to indicate their answer on a blank card and place the card in an envelope, which they sealed and returned to the interviewer; they were informed that the principal investigators (but not the interviewers) would be able to link their responses in the face-to-face interview with that reported in the sealed envelope ${ }^{24}$ Finally, textual data, drawn from presurvey focus group discussions and key informant interviews, enabled researchers to corroborate the evidence presented in survey data.

\section{Measures}

- Outcome measures. We included three key outcome indicators. The first measures whether or not young people had ever had a romantic relationship. Those who reported a ro- mantic opposite-sex relationship were asked whether they had ever held hands, hugged, kissed on the lips or had sex with that partner. Respondents were also asked whether they had experienced sex in other situations. Key indicators included whether or not the respondent had ever had a premarital romantic relationship with a person of the opposite sex, whether they had experienced any physical intimacy with a romantic partner and whether they had engaged in sexual relations with a romantic partner or in a number of other situations.

- Individual characteristics. Key indicators included respondents' age, educational attainment and economic activity, and their exposure to alcohol, drugs and pornographic films. In addition, youth were asked a range of questions concerning their ability to have a voice in determining their own lives, including such dimensions of agency as mobility and sense of self-worth. To measure mobility, we created an index that summed the number of places out of a total of five-a local shop, a friend's house, a film or fair (mela), a temple or mosque, and anywhere outside the neighborhood-young people said they could visit without obtaining permission. Scores on this index ranged from 0 (for those who required permission to visit all five places) to 5 (for those who could visit any of the five places without permission). Self-worth was measured by two dichotomous variables: whether respondents felt that their opinions were respected by their family and whether they found it easy to build new friendships.

- Peer influence and connections. We included four measures of peer influence and connections: an index of youth norms regarding the acceptability of premarital sex in the urban neighborhood or village of residence, membership in a social group, peer contact and peer support. The youth norm index was based on youth agreement or disagreement with four statements: that it was all right for young men and women to kiss, hug and touch each other; that there was nothing wrong with engaged couples having sex before marriage; and that it was all right for young men and young women, respectively, to have sex before marriage. Respondents were assigned a score of 1 if they agreed with the statement and zero if not.

To construct the youth norm index, we first summed responses of all individuals to the four statements concerning the acceptability of premarital sex. We then calculated the average for each gender in each village or urban block. Each respondent residing in a specific village or urban block was assigned the mean value for males or females in that community; the index ranged from 0 to 4 , with 0 signifying that youth in a community considered premarital sex unacceptable in all four situations and 4 signifying that youth considered it acceptable in all four situations.

We measured membership in a social group (mandal) by a dichotomous indicator. Peer contact was measured by an index of the frequency of respondents' interaction with peers, ranging from 0 (never) to 3 (regularly). Finally, peer support was measured by an index of the extent to which respondents identified peers as their most likely confidants 
on life issues. Youth were asked with whom (among a range of options including peers, parents, siblings, extended kin, teachers and so on) they would be most likely to discuss issues related to health, education, work, relationships with the opposite sex, menstruation (young women) or nocturnal emission (young men), and family matters. A score of 1 was assigned for each of the six types of issues for which peers were identified as the most likely confidants; thus, the index ranged from 0 to 6 .

- Family influences. We included dichotomous measures of residence in a two-parent household, observation or experience of family violence, paternal substance use and perceived parental strictness. In addition, we constructed an index of parental support-identical to the index of peer support discussed above-that summed how many times respondents identified a parent as their most likely confidant on six types of life issues; the index ranged from 0 to 6. In addition, background characteristics of youth were collected, including, for example, religion, housing amenities, household economic status and parental educational attainment.

\section{Data Analysis}

We first calculated the proportions of young males and females in each setting (urban or rural) who reported aspects of romantic and sexual partnerships, and the proportions reporting selected individual, peer and family characteristics. In each case, t-tests were calculated to identify significant differences between young women and men in each setting.

Finally, we conducted multivariate logistic regression analyses to identify associations between selected individual, peer and family factors and youths' relationship experience.* The first analysis examined romantic partnerships of males and females with a member of the opposite sex. Because few young women reported sexual intercourse, the second analysis focused on young women's experience of physical intimacy with a romantic partner (defined as holding hands, hugging, kissing on the lips or sexual intercourse) or sex with any other partner. In the third analysis, the dependent variable was young men's experience of sexual intercourse with any partner (i.e., romantic partner, sex worker or other). Data were weighted to reflect the rural-urban distribution of Pune District.

\section{RESULTS}

\section{Respondent Characteristics}

In all four groups, the vast majority (83-92\%) of the young people who responded to questions on partnerships were Hindu (Table 1). Economic status, as measured by the mean number of seven consumer goods owned (TV, telephone, pressure cooker, mobile phone, bicycle, motorcycle or car and VCR), appears to be similar across groups (2.7-3.3), although rural households typically possessed slightly fewer

*Because we were testing a theoretical model, we included all variables in a single model. No correlation between any two independent variables included in this model exceeded 0.20 . amenities than urban households. A large majority of urban and rural youth (87-98\%) reported that their households had electricity, but a larger proportion of urban respondents than of rural respondents cooked with gas (80-86\% vs. $45-51 \%)$ or had access to piped or well water within the home (69-87\% vs. 35-38\%). In contrast, a larger proportion of rural youth than of urban youth reported having toilet facilities in their home (21-27\% vs. 7-8\%).

\section{Partnerships and Sexual Relations}

About one-third of urban males and females and one-fourth of rural males and females reported having made or received a proposal of romantic partnership (Table 2, page 154). Within each setting, a larger proportion of young men than of young women had made or received such proposals; however, the extent to which proposals were accepted and the nature of subsequent relationships varied widely by the respondent's gender and residence. In the urban setting, $24 \%$ of males and $8 \%$ of females reported ever having had a romantic partner; the proportions in the rural setting were $17 \%$ and $5 \%$. According to findings from a life table analysis using Kaplan-Meier estimates that examined the probability of having spent time alone with the partner by age 16 (not shown), 11\% percent of urban males and $7 \%$ of rural males had done so; the proportions among females were $6 \%$ and $4 \%$.

Overall, $18 \%$ of urban males and $16 \%$ of rural males reported having had sexual intercourse, compared with $1 \%$ and $2 \%$ of females. When we probed about type of partner, $8-9 \%$ of young men and fewer than $1 \%$ of females reported having had sex with a romantic partner. Some $9 \%$ and 3\% of urban and rural young men, respectively, had had other sexual experiences, including sex with another man, exchange or paid sex, forced sex or sex with an older married woman; a very small proportion of young women (fewer than $1 \%$ ) reported forced sex, exchange sex or same-sex relations. Also, a small proportion of young men-particularly in urban

\begin{tabular}{|c|c|c|c|c|}
\hline \multirow[t]{2}{*}{ Characteristic } & \multicolumn{2}{|l|}{ Urban } & \multicolumn{2}{|l|}{ Rural } \\
\hline & $\begin{array}{l}\text { Male } \\
(\mathrm{N}=817)\end{array}$ & $\begin{array}{l}\text { Female } \\
(\mathrm{N}=1,784)\end{array}$ & $\begin{array}{l}\text { Male } \\
(\mathrm{N}=870)\end{array}$ & $\begin{array}{l}\text { Female } \\
(\mathrm{N}=1,799)\end{array}$ \\
\hline \multicolumn{5}{|l|}{ Religion } \\
\hline Hindu & 85.2 & 82.6 & 91.5 & 88.4 \\
\hline Muslim & 9.4 & 7.0 & 2.4 & 2.8 \\
\hline Christian & 0.4 & 0.2 & 0.2 & 0.3 \\
\hline Buddhist & 5.0 & 10.2 & 5.9 & 8.5 \\
\hline \multicolumn{5}{|c|}{ Mean no. of consumer } \\
\hline goods owned $t$ & 3.3 & 3.3 & 2.8 & 2.7 \\
\hline \multicolumn{5}{|c|}{ Household amenities } \\
\hline Has own toilet & 6.7 & 7.9 & 21.3 & 27.0 \\
\hline Has electricity & 98.3 & 98.0 & 87.4 & 88.1 \\
\hline Cooks with gas & 79.7 & 86.1 & 44.9 & 51.2 \\
\hline Has own water & 68.7 & 87.4 & 35.2 & 38.3 \\
\hline
\end{tabular}




\begin{tabular}{|c|c|c|c|c|}
\hline \multirow[t]{2}{*}{ Characteristic } & \multicolumn{2}{|l|}{ Urban } & \multicolumn{2}{|l|}{ Rural } \\
\hline & Male & Female & Male & Female \\
\hline All & $(\mathrm{N}=815)$ & $(\mathrm{N}=1,777)$ & $(\mathrm{N}=870)$ & $(\mathrm{N}=1,792)$ \\
\hline $\begin{array}{l}\text { Ever made/received a proposal of } \\
\text { romantic partnership }\end{array}$ & 36.0 & $30.8^{* *}$ & 26.4 & $25.9^{*}$ \\
\hline Ever had a romantic partner & 24.2 & $8.0^{* * *}$ & 17.0 & $4.7^{* *}$ \\
\hline Ever had sexual intercourse & $17.5+$ & $1.3^{* * *}$ & $15.5 \dagger$ & $2.2^{* *}$ \\
\hline With a romantic heterosexual partner & 9.1 & $0.5^{* * *}$ & 8.4 & $0.6^{* *}$ \\
\hline With other partner $\neq$ & 9.0 & $0.1^{* * *}$ & 3.3 & $0.1^{* *}$ \\
\hline Reported by sealed envelope & & & & \\
\hline having ever had sex & 2.6 & $0.7^{* * *}$ & 4.8 & $1.5^{* *}$ \\
\hline Had sex with romantic partner and other(s) & 3.1 & $0.0^{* * *}$ & 1.0 & $0.0^{* *}$ \\
\hline Ever engaged in any physical intimacy§ & 26.4 & $5.6^{* * *}$ & 20.2 & $4.3^{* * *}$ \\
\hline $\begin{array}{l}\text { Respondents reporting a } \\
\text { romantic relationship }\end{array}$ & $(\mathrm{N}=198)$ & $(N=142)$ & $(N=148)$ & $(\mathrm{N}=\mathbf{8 5})$ \\
\hline Ever engaged in any physical intimacy§ & 85.4 & $63.4^{* * *}$ & 84.5 & $57.6^{* *}$ \\
\hline Ever kissed or had sex & 77.3 & $35.9^{* * *}$ & 75.7 & $40.0^{* *}$ \\
\hline Ever had sex & 37.4 & $6.3^{* * *}$ & 49.3 & $12.9^{* *}$ \\
\hline Expect to marry romantic partner & 61.1 & $78.9^{* * *}$ & 66.9 & $87.1^{* *}$ \\
\hline $\begin{array}{l}\text { Mean age difference between male } \\
\text { partner and female partner }\end{array}$ & 1.2 & $2.9 * * *$ & 1.4 & $3.1^{* *}$ \\
\hline Parents aware of relationship & 38.4 & $49.3^{*}$ & 29.7 & 37.6 \\
\hline Peers aware of relationship & 82.3 & 84.5 & 83.1 & 82.4 \\
\hline
\end{tabular}

*Significantly different from males at $p<.05$. ${ }^{*}$ Significantly different from males at $p \leq .01 .{ }^{* * *}$ Significantly different from males at $p \leq .001$. †A respondent may have had sex with both a romantic partner and someone else, hence the sum of percentages for subcategories may exceed the total. \#Sexual experiences with other partner include sex with a person of the same gender; exchange or paid sex; forced sex; and for men, sex with an older married woman. SIncluding sex. Note: All figures are percentages, unless otherwise indicated.

areas-who reported sex in the face-to-face interview reported sex with both a girlfriend and at least one other partner. In addition, $3-5 \%$ of young men and $1-2 \%$ of young women reported by sealed envelope (but not in their interview), that they had experienced sexual relations. Some $20-26 \%$ of young men and $4-6 \%$ of young women reported ever having experienced any kind of physical intimacy with a romantic opposite-sex partner or sexual intercourse with anyone.

When we considered only respondents who had had a

\section{TABLE 3. Selected characteristics of survey respondents, by urban or rural residence and gender}

\begin{tabular}{lcc|rr} 
& Urban & & Rural \\
\cline { 2 - 5 } Characteristic & Male & Female & Male & Female \\
\hline Mean age & 19.0 & $17.4^{* * *}$ & 19.1 & $17.1^{* * *}$ \\
Age <20yrs. & 39.5 & $15.6^{* * *}$ & 39.2 & $10.7^{* * *}$ \\
Completed $\geq 8$ years of school & 80.0 & 80.9 & 80.7 & $72.8^{* * *}$ \\
Mean yrs. of schooling & 9.3 & 9.5 & 9.5 & $8.9^{* * *}$ \\
Paid work in last 12 mos. & 67.0 & $34.2^{* * *}$ & 63.6 & $26.8^{* * *}$ \\
Mobility index score (range 0-5) & 3.0 & $1.6^{* * *}$ & 3.2 & $1.7^{* * *}$ \\
Can visit without permission & & & & \\
$\quad$ Shop & 70.9 & $60.9^{* *}$ & 78.5 & $55.8^{* * *}$ \\
Friend's house & 68.7 & $47.4^{* * *}$ & 77.0 & $52.2^{* * *}$ \\
Film/fair & 55.7 & $7.3^{* * *}$ & 54.7 & $7.6^{* * *}$ \\
$\quad$ Temple/mosque & 78.5 & $42.6^{* *}$ & 87.8 & $49.5^{* * *}$ \\
$\quad$ Outside the neighborhood & 28.2 & $4.0^{* * *}$ & 25.2 & $6.6^{* * *}$ \\
Opinion respected by family & 91.9 & 87.5 & 94.9 & 90.7 \\
Makes friends easily & 24.5 & 30.7 & 17.7 & $30.4^{* *}$ \\
Exposure to alcohol/drugs/pornographic films & & & & \\
$\quad$ Any & 57.1 & $1.9^{* * *}$ & 41.4 & $1.0^{* * * *}$ \\
$\quad$ Alcohol/drugs & 24.8 & $1.4^{* * *}$ & 13.0 & $0.7^{* * *}$ \\
$\quad$ Pornographic films & 52.8 & $0.6^{* * *}$ & 37.6 & $0.3^{* * *}$ \\
\hline
\end{tabular}

*Significantly different from males at $p<.05$. ${ }^{* *}$ Significantly different from males at $p \leq .01$. ${ }^{* *}$ Significantly different from males at $\mathrm{p} \leq .001$. Note: All figures are percentages, unless otherwise indicated. romantic partnership, $85 \%$ of young men and about $60 \%$ of young women reported having experienced any type of physical intimacy, including holding hands, hugging, kissing or sex; smaller proportions had ever kissed or had sex (76-77\% of males and 36-40\% of females) and still smaller proportions had had sex (37-49\% of males and 6-13\% of females). Young men were typically $1-3$ years older than their partners.

A smaller proportion of young men than of young women had entered their current relationship with expectations of marriage. This finding was supported by data from indepth interviews:

"No, not at all [did I want to marry her]. For time-pass, I got friendly with her."-19-year-old urban male

"I asked him if he would get married to me or not. He would only say yes....When I would ask him anything, he would say that when the time comes, we shall talk....I would think that he did not want to get married to me because whenever I would talk about it he would change the topic and if he wanted to get married to me, he himself would have brought up the topic."-17-year-old rural female

Finally, although $82-85 \%$ of youth in a partnership reported that their peers were aware of the relationship, only $30-49 \%$ said that their parents knew about it.

\section{Individual, Peer and Family Factors}

- Individual characteristics. On average, young men in the sample were older than young women (19 years vs. 17 years-Table 3). A large majority (73-81\%) of young people had completed eight or more years of school. In the 12 months preceding the survey, $64-67 \%$ of males had engaged in a wage-earning activity, compared with $27-34 \%$ of females.

There was a large gender difference in mobility, with young males reporting greater freedom of movement than young women (mobility index score, 3.0-3.2 vs. 1.6-1.7). Gender differences in indicators of self-worth were mixed. For instance, $92-95 \%$ of males and $88-91 \%$ of females reported that their views were respected by their family; however, confidence in one's ability to forge new friendships was reported by greater proportions of females (30-31\%) than of males (18-25\%).

Finally, large gender differences were apparent in exposure to alcohol, drugs and pornographic films. Fifty-seven percent of urban males and $41 \%$ of rural males reported having used alcohol or drugs, or having been exposed to a pornographic film, compared with $2 \%$ and $1 \%$ of females, respectively.

- Peer influence and connections. Mean youth norm index scores were low among young men (0.6-0.7-Table 4) and lower still among young women $(0.1-0.2)$, indicating that norms about premarital sex remain traditional overall. Large gender differences in aspects of young people's peer networks were evident. A much smaller proportion of young women than of young men reported being a member of a social group (4-5\% vs. 44-56\%), and young women reported having fewer friends than did young men (averages 
of five and 15-19 friends, respectively). Furthermore, young women scored lower, on average, than young men on the peer contact index (0.7-0.8 vs. 1.7-1.8) and peer support index (0.7-0.8 vs. 1.6-1.7), suggesting that young women are in touch with and confide in their friends less frequently. - Family and parental influences. At least $74 \%$ of youth resided in two-parent homes, and more than 90\% lived with at least one parent (Table 5, page 156). On average, youth were better educated than their parents: Whereas youth had completed 9-10 years of school, their fathers had had 5-6 years and their mothers $2-3$ years.

Clear gender differences were observed in youth perceptions of parental strictness, underlining the greater permissiveness with which young males are socialized. Although $40-41 \%$ of young women reported their parents to be strict, only $28-32 \%$ of males did so. This finding is reinforced by data from focus group discussions. For example, an urban female said, "If we start a friendship with a boy, if he meets us somewhere and if our parents see us talking then something might come to their minds... parents are really very strict."

A sizeable minority of respondents depicted their family life as involving violence and substance use. Overall, 12-19\% of youth reported having witnessed their father beating their mother, with little difference by gender; $8-15 \%$ of young women and $22-32 \%$ of young men reported having been beaten by a family member, usually a parent. Some 28-45\% of youth reported paternal substance use (mainly alcohol).

On average, young women scored higher than men on the index of family support (4.3-4.4 vs. 2.5-2.7); however, both genders confided about more matters to family than to peers. The exception was problems in relationships with the opposite sex: Some $45-63 \%$ of youth confided in peers about such matters, whereas $16-27 \%$ confided in parents. In addition, young men tended to confide more in peers about nocturnal emission, whereas young women confided more in their mother about menstruation.

\section{Partnership Progression: Correlates}

In multivariate analyses, factors from all three levels-individual, peer and parental-were found to be associated with romantic partnerships and physical intimacy for females; only individual and peer factors were linked to sexual relations for males (Table 6, page 157). Several individual factors were associated with partnership formation for both young women and young men. For example, age was positively associated with the odds of having had a romantic partnership for females (odds ratio, 1.1) and of having had sex for males (1.1); education was negatively associated with the odds of forming a romantic partnership or of engaging in physical intimacy for females (odds ratio, 0.9 each), and of having sex for males (0.9). Exposure to alcohol, drugs or pornographic films was positively associated with all outcomes, for both young men and young women (3.5-5.7).

Differences by gender, however, were also apparent: Among young men but not young women, current wage
TABLE 4. Selected measures of peer influence and connections, by respondents urban or rural residence and gender

\begin{tabular}{|c|c|c|c|c|}
\hline \multirow[t]{2}{*}{ Measure } & \multicolumn{2}{|c|}{ Urban } & \multicolumn{2}{|l|}{ Rural } \\
\hline & Male & Female & Male & Female \\
\hline \multicolumn{5}{|l|}{ Youth norms } \\
\hline Mean youth norms index score (range, $0-4$ ) & 0.70 & $0.15^{* * *}$ & 0.63 & $0.07 * * *$ \\
\hline \multicolumn{5}{|l|}{ Attitudes about premarital relations } \\
\hline $\begin{array}{l}\text { It is all right for young men and women to kiss, } \\
\text { hug and touch each other }\end{array}$ & 29.0 & $5.1^{* * *}$ & 27.5 & $4.0^{* * *}$ \\
\hline \multicolumn{5}{|l|}{ There is nothing wrong with engaged couples } \\
\hline \multicolumn{5}{|l|}{ It is all right for young men to have sex } \\
\hline \multicolumn{5}{|l|}{ It is all right for young women } \\
\hline to have sex before marriage & 14.0 & $3.1^{* * *}$ & 11.5 & $0.5^{* * *}$ \\
\hline \multicolumn{5}{|l|}{ Group membership } \\
\hline Member of at least one group (mandal) & 56.3 & $4.3^{* * *}$ & 44.3 & $5.2^{* * *}$ \\
\hline \multicolumn{5}{|l|}{ Peer networks } \\
\hline Mean no. of same-sex friends & 19.3 & $4.8^{* * *}$ & 15.4 & $4.6^{* * *}$ \\
\hline Mean peer contact index score (range, $0-5$ ) & 1.8 & $0.8^{* * *}$ & 1.7 & $0.7^{* * *}$ \\
\hline \multicolumn{5}{|l|}{ Peer interaction } \\
\hline Mean peer support index score (range, $0-6$ ) & 1.65 & $0.78^{* * *}$ & 1.62 & $0.73 * * *$ \\
\hline \multicolumn{5}{|l|}{ Peers are leading confidants about problems with: } \\
\hline Physical health & 6.9 & 3.5 & 8.4 & $2.2^{* *}$ \\
\hline Work & 10.2 & 7.4 & 9.7 & $1.6^{* *}$ \\
\hline Education & 6.7 & 3.5 & 7.1 & $2.1^{* *}$ \\
\hline Male-female relationships & 63.4 & $45.1^{* * *}$ & 60.6 & $51.0^{* *}$ \\
\hline Menstruation/nocturnal emission & 69.6 & $6.7^{* * *}$ & 64.4 & $6.9^{* * *}$ \\
\hline Family & 8.3 & $14.3^{* *}$ & 11.5 & $8.7^{* *}$ \\
\hline
\end{tabular}

*Significantly different from males at $\mathrm{p}<.05$. ${ }^{* *}$ Significantly different from males at $\mathrm{p} \leq .01$. ${ }^{* *}$ Significantly different from males at $\mathrm{p} \leq .001$. Note: All figures are percentages, unless otherwise noted.

work was associated with having formed a romantic partnership (odds ratio, 1.5) and mobility was associated with having experienced a sexual relationship (1.1). In contrast, women who perceived themselves as being able to make friends easily had elevated odds of having had romantic and physical relationships (1.6 for each); among men, this factor had only a marginally significant relationship with the formation of romantic partnerships (1.4).

Of the peer-related factors, greater community-level acceptance of premarital sex was strongly associated with romantic partnership formation for males and females, physical intimacy for females and sex for males (odds ratios, 2.1-5.2), as was greater frequency of peer contact (1.3-1.6). The influence of other peer factors was less consistent. Group membership was strongly associated with romantic partnership formation for males (odds ratio 1.6); peer support was associated with physical intimacy for females (odds ratio 1.2).

Qualitative data confirmed that in the area of romantic and sexual relations, peers-particularly for young menoffered support in many ways, ranging from providing space where a couple could meet to giving advice on appropriate methods of contraception, as revealed in the following:

"We have friends with whom we discuss everything.... And having such friendships is necessary since we discuss such things [romance, sex] only amongst friends. We never discuss such things with family members."-focus group discussion, urban males 


\begin{tabular}{|c|c|c|c|c|}
\hline \multirow[t]{2}{*}{ Measure } & \multicolumn{2}{|c|}{ Urban } & \multicolumn{2}{|l|}{ Rural } \\
\hline & Male & Female & Male & Female \\
\hline \multicolumn{5}{|l|}{ Living situation } \\
\hline Lives with both parents & 74.5 & $82.9 * * *$ & 82.9 & $88.7^{* * *}$ \\
\hline Lives with one or both parents & 91.0 & $96.5^{* * *}$ & 94.4 & $97.2^{* *}$ \\
\hline \multicolumn{5}{|l|}{ Parents' socioeconomic status } \\
\hline \multicolumn{5}{|l|}{ Mean years of schooling } \\
\hline Fatherst & 5.3 & $5.7^{* *}$ & 4.8 & $5.5^{* * *}$ \\
\hline Motherst & 2.5 & $3.1^{* * *}$ & 1.9 & $2.4^{* * *}$ \\
\hline Mean no. of consumer goods owned $\neq$ & 3.3 & 3.3 & 2.8 & 2.7 \\
\hline \multicolumn{5}{|l|}{ Socialization/family violence/substance use } \\
\hline Parents are strict & 27.6 & $41.2^{* * *}$ & 31.8 & $40.3^{* * *}$ \\
\hline Father beats mother & 18.7 & 18.7 & 13.3 & 11.8 \\
\hline Respondent beaten by family & 31.5 & $15.3^{* * *}$ & 22.3 & $8.4^{* * *}$ \\
\hline Father uses alcohol/drugs & 44.1 & 44.8 & 31.8 & $27.6^{*}$ \\
\hline \multicolumn{5}{|l|}{ Parental closeness } \\
\hline Mean family support index score (range, 0-6) & 2.7 & $4.3^{* * *}$ & 2.5 & $4.4^{* * *}$ \\
\hline \multicolumn{5}{|l|}{ Family are leading confidants about problems with: } \\
\hline Physical health & 78.6 & $87.2^{* *}$ & 79.7 & $88.3^{* *}$ \\
\hline Work & 52.5 & $64.4^{* *}$ & 44.7 & $58.2^{* *}$ \\
\hline Education & 31.5 & $60.9 * * *$ & 28.7 & $56.0^{* * *}$ \\
\hline Male-female relationships & 16.2 & $26.5^{* *}$ & 20.0 & 22.9 \\
\hline Menstruation/nocturnal emission & 14.4 & $82.2^{* * *}$ & 19.3 & $81.4^{* * *}$ \\
\hline Family & 72.5 & 71.2 & 71.8 & $78.0^{* *}$ \\
\hline
\end{tabular}

*Significantly different from males at $p<.05$. **Significantly different from males at $p \leq .01$. ***Significantly different from males at $p \leq 001$. †Excludes those reporting "don't know." ¥Television, telephone, pressure cooker, mobile phone, motorcycle/car, bicycle, VCR. Note: All figures are percentages, unless otherwise noted.

"[We had sex] there only-in my friend's house. She [the friend] used to wait outside or would go somewhere." -in-depth interview, urban female, age 16

"My friends told me that if a condom is used then the girl does not get pregnant."-in-depth interview, rural male, age 21

In contrast, family influences and connections were more likely to be associated with outcome measures for young women than for young men. For example, young women who reported having a close relationship with their parents had reduced odds of forming romantic relationships (odds ratio, 0.9), while those who had witnessed their father beating their mother had elevated odds of forming such relationships (1.6). Young women who had been beaten by their family were significantly more likely to form romantic (3.0) and sexual (2.6) partnerships.

In focus group discussions and in-depth interviews, young women and some young men themselves made the link between parental support and partnership formation. For example:

"Why does a boy or a girl go out? It is when there is no one at home who understands him or her....Then with whom should they share their problems? When he faces this problem, then he starts searching for a solution [opposite sex friend] in the neighborhood."-focus group discussion, urban males

"Sometimes if in the family, someone is not getting love, or if every day the father comes home drunk...in such situations one tends to find some support outside."-in-depth interview, urban female, age 23
In regard to parental monitoring, youth who reported parental strictness were no less likely than others to report a relationship that included any physical intimacy (females) or to have engaged in sex (males). Textual data suggest that opportunities do arise, despite strict supervision, for youth to find moments of privacy:

"I told her that whatever they do after marriage, I wanted to do it only once. In the beginning she did not agree but afterwards she told me that on Saturday afternoon her family was going out. She told me that she would be at home."-in-depth interview, rural male, age 20

"When I used to go to school he used to come behind me. Sometimes he used to meet me and tell me [where to meet]. So I used to tell my parents I had class or some programme in school."-in-depth interview, 19-year-old urban female

\section{DISCUSSION}

Our study builds on previous research and makes several new and important contributions to understanding the levels and correlates of premarital relationships among youth. Our findings are community-based and reiterate that even in this traditional setting, opportunities do exist for social mixing between young men and women, and that expressions of interest in developing intimacy with the opposite sex are not uncommon. Opportunities also exist for the formation of romantic partnerships among unmarried youth, for physical intimacy (including sex) within such partnerships and for sex with romantic and other partners. Overall, 16-18\% of young men and 1-2\% of young women reported having had sex-levels that fall within the broad range reported in other smaller and less representative studies conducted in India. ${ }^{1-6}$

In addition, our study adds to the limited body of research on the associations between individual, peer and family factors and the formation of premarital romantic partnerships and engagement in premarital physical intimacy or sex. .,8-17 $^{-17}$ Our findings, like those of previous research, ${ }^{4}$ suggest that age, education, frequency of peer contact, positive attitudes toward premarital sex and exposure to alcohol, drugs or pornographic films are indeed correlated with romantic or sexual experience for both young women and young men.

Our data also show gender differences in correlates of premarital relationships. For young women, romantic relationships were negatively associated with closeness to parents and positively associated with having seen their father beat their mother. Young women who had been beaten by their families had elevated risks of forming romantic and physically intimate relationships. These correlations did not appear among young men.

Although peer influences were associated with increased odds of physical intimacy and sex among young women and men, the associations tended to be stronger among young women. Peer support may enable closely guarded young women to defy traditional norms, to exercise individual choice and to engage in nonconformist behavior, whereas young men face fewer restrictions and therefore 


\begin{tabular}{|c|c|c|c|c|}
\hline \multirow[t]{2}{*}{ Characteristic } & \multicolumn{2}{|c|}{ Romantic partnership } & \multirow{2}{*}{$\begin{array}{l}\text { Physical intimacy or sex } \neq \\
\text { Females } \\
(\mathrm{N}=3,569)\end{array}$} & \multirow{2}{*}{$\begin{array}{l}\text { Sex§ } \\
\text { Males } \\
(\mathrm{N}=1,685)\end{array}$} \\
\hline & $\begin{array}{l}\text { Females } \\
(\mathrm{N}=3,569)\end{array}$ & $\begin{array}{l}\text { Males } \\
(\mathrm{N}=1,685)\end{array}$ & & \\
\hline \multicolumn{5}{|l|}{ Individual attributes } \\
\hline Age & $1.10(1.01-1.19)^{*}$ & $1.05(0.98-1.12)$ & $1.06(0.97-1.17)$ & $1.09(1.02-1.17)^{*}$ \\
\hline Yrs. of schooling completed & $0.92(0.87-0.98)^{* *}$ & $0.98(0.93-1.04)$ & $0.92(0.86-0.99)^{*}$ & $0.87(0.83-0.93)^{* * *}$ \\
\hline Paid work in last 12 mos. & $1.31(0.94-1.82)$ & $1.53(1.07-2.18)^{*}$ & $1.35(0.93-1.97)$ & $1.41(0.95-2.08) \dagger$ \\
\hline Mobility index & $1.05(0.93-1.19)$ & $1.09(1.00-1.20) \dagger$ & $1.04(0.92-1.20)$ & $1.12(1.02-1.23)^{*}$ \\
\hline Opinion respected by family & $0.84(0.50-1.39)$ & $1.17(0.60-2.30)$ & $0.83(0.47-1.48)$ & $0.75(0.36-1.56)$ \\
\hline Makes friends easily & $1.62(1.18-2.24)^{* * *}$ & $1.38(1.00-1.89) \dagger$ & $1.60(1.11-2.29)^{*}$ & $0.89(0.61-1.29)$ \\
\hline Alcohol/drugs/pornographic films & $5.66(2.63-12.18)^{* * *}$ & $3.62(2.60-5.05)^{* * *}$ & $5.15(2.37-11.22)^{* * *}$ & $3.49(2.47-4.93)^{* * *}$ \\
\hline \multicolumn{5}{|l|}{ Peer influences } \\
\hline Acceptance of premarital sex & $5.16(2.19-12.18)^{* * *}$ & $2.06(1.20-3.55)^{* *}$ & $3.89(1.50-10.07)^{* *}$ & $2.83(1.61-5.00)^{* * *}$ \\
\hline Group membership & $0.85(0.41-1.78)$ & $1.61(1.20-2.16)^{* *}$ & $0.94(0.43-2.05)$ & $1.28(0.93-1.76)$ \\
\hline Peer contact index & $1.63(1.40-1.90)^{* * *}$ & $1.28(1.13-1.45)^{* * * *}$ & $1.63(1.37-1.95)^{* * *}$ & $1.25(1.10-1.42)^{* * *}$ \\
\hline Peer support index & $1.20(1.02-1.40)$ & $1.13(1.00-1.28)$ & $1.24(1.04-1.47)^{* *}$ & $1.06(0.93-1.22)$ \\
\hline \multicolumn{5}{|l|}{ Family influences } \\
\hline Lives with both parents & $1.20(0.76-1.89)$ & $0.78(0.53-1.12)$ & $1.65(0.91-3.01) \dagger$ & $0.97(0.66-1.44)$ \\
\hline Parental strictness & $1.32(0.96-1.82) \dagger$ & $1.30(0.95-1.77) \dagger$ & $1.03(0.72-1.47)$ & $1.25(0.89-1.76)$ \\
\hline Parental support index & $0.86(0.76-0.96)^{* *}$ & $1.06(0.93-1.20)$ & $0.88(0.77-1.00) \dagger$ & $0.93(0.81-1.06)$ \\
\hline Father beats mother & $1.55(1.03-2.33)^{*}$ & $1.30(0.88-1.93)$ & $1.48(0.97-2.26) \dagger$ & $1.32(0.86-2.04)$ \\
\hline Respondent beaten by family & $2.95(1.94-4.48)^{* * *}$ & $1.10(0.79-1.53)$ & $2.59(1.64-4.07)^{* * *}$ & $0.94(0.64-1.39)$ \\
\hline No. of consumer goods owned & $0.93(0.84-1.03)$ & $1.17(1.06-1.29)^{* * *}$ & $0.96(0.86-1.07)$ & $1.10(1.00-1.21) \dagger$ \\
\hline Mother's yrs. of schooling & $0.99(0.94-1.05)$ & $0.94(0.90-0.99)^{* *}$ & $0.98(0.93-1.04)$ & $0.97(0.92-1.01)$ \\
\hline Urban residence & $1.39(1.02-1.88)^{*}$ & $1.11(0.85-1.46)$ & $1.06(0.75-1.48)$ & $0.86(0.64-1.15)$ \\
\hline Pseudo R2 & .14 & .16 & .11 & .14 \\
\hline
\end{tabular}

${ }^{*} \mathrm{p}<.05 .{ }^{* *} \mathrm{p}<.01 .{ }^{* * *} \mathrm{p}<.001 . \dagger \mathrm{p}<.10$. $\neq$ Any physical intimacy, including sex with romantic partner, sex with same-sex partner, forced sex, exchange sex, or sex reported by sealed envelope. §Sex with romantic partner, same-sex relationship, forced sex, paid sex, sex with an older married woman, or sex reported by sealed envelope.

are less likely to require peer support to engage in nonconformist-including sexual-behavior. Also, our data suggest that young men's greater mobility and greater access to resources enable them to form romantic or sexual relationships; in contrast, among young women, it is clearly those who express agency-in terms of the ability to forge new friendships-who are able to overcome parental restrictions on mobility and form relationships.

Finally, our finding of a marginal, positive relationship between the strictness of socialization and engagement in romantic partnerships and the lack of association with physical intimacy or sex suggests that parental beliefs that strict supervision of children may inhibit their formation of romantic or sexual relationships may be unfounded. On the other hand, as seen previously in the literature, ${ }^{2}$ closeness to parents may discourage the early formation of romantic relationships for young women, while family violence may raise the risk of all types of relationships.

\section{Limitations}

Potential limitations of our study must be acknowledged. First, youth in our sample may have underreported their romantic, physical and sexual experiences-a limitation observed in most studies of this nature. ${ }^{7,26}$ Pune is a traditional setting, where powerful norms inhibit premarital friendships with the opposite sex, whether they are platonic, romantic or sexual. In such a setting, relationships are usually carried on secretly, and youth-particularly young females, who have more to lose than young males-may be unwilling to disclose them. And although young males may have been more forthcoming than young females in their reporting of romantic partnerships, they may have underreported their same-sex or transactional sex experiences. We attempted to reduce underreporting by arranging the progression of survey questions from less to more sensitive, and by giving respondents the opportunity to report sexual behavior anonymously. Reporting in our study is consistent with that in other studies in India, ${ }^{1-6}$ few of which extended their samples to youth at the lower end of the age spectrum (i.e., 15-16). Thus, although we cannot rule out the underreporting of premarital experiences and possible measurement error, we believe that they are unlikely to be of sufficient magnitude to compromise the validity of our findings.

A second potential limitation is the cross-sectional nature of our study and the resulting inability to infer causation. Our study findings cannot be interpreted as evidence of the determinants of romantic partnerships, physical intimacy or sexual relations; however, in some cases-notably parental factors-temporal ordering rules out the possibility that causality could go in either direction. Qualitative evidence strengthens the suggestion of a causal link between some of the associations observed in multivariate analyses-for example, between family instability or closeness, the supportive role of parents and engagement in romantic or physical relationships. 


\section{Program Implications}

The declining age at puberty and the increasing age at marriage have created a growing period in which young people may engage in premarital romantic and sexual relations. Likewise, evidence that large proportions of youth remain in school for extended periods suggests that opportunities to spend time together in acceptable spaces away from the watchful eyes of parents will increasingly present themselves. The challenge is, therefore, for programs to ensure that young women and men are fully informed and equipped to make safe choices and negotiate wanted outcomes. Sexuality education must be made universal, and should address relationship issues as well as consent and safety from an early age in schools and other settings in which young people congregate.

Our findings also highlight the importance of peer networks, which can have a positive or negative influence on the safety and wantedness of young people's relationships. At present, it appears that the network plays a role in enabling the establishment of romantic or sexual relations. Good sexuality education may enable peers to play a role in ensuring that these are safe and wanted as well.

Also needed are efforts to ensure a supportive environment; programs need to address parental inhibitions about discussing sexual matters with their children and encourage greater openness and interaction between parents and children. Finally, gender disparities in the extent and correlates of premarital partnership formation and experience of sexual relations argue against generic programming. They suggest a need for sexuality education programs tailored to the different circumstances and experiences of young women and men; and for programs that sensitize parents about more equitable socialization patterns and ways of developing closer interaction with both daughters and sons.

\section{REFERENCES}

1. Jejeebhoy SJ and Sebastian MP, Young people's sexual and reproductive health, in: Jejeebhoy SJ, ed., Looking Back, Looking Forward: A Profile of Sexual and Reproductive Health in India, New Delhi: Population Council, and Jaipur, India: Rawat Publications, 2004, pp. 138-168.

2. Mehra S, Savithri R and Coutinho L, Sexual behavior among un married adolescents in Delhi, India: opportunities despite parental controls, 2002, paper presented at the 2002 IUSSP Regional Population Conference, Bangkok, June 10-13, 2002.

3. Potdar R and Koenig MA, Does Audio-CASI improve reports of risky behavior? Evidence from a randomized field trial among urban men in India, Studies in Family Planning, 2005, 36(2):107-116.

4. Abraham L and Kumar KA, Sexual experiences and their correlates among college students in Mumbai City, India, International Family Planning Perspectives, 1999, 25(3):139-146.

5. Awasthi S, Nichter M and Pande VK, Developing an interactive STD prevention program for youth: lessons from a north Indian slum, Studies in Family Planning, 2000, 31(2):138-150.

6. Kaur U et al., Sexual behaviour, drug use and hepatitis B infection in Chandigarh students, National Medical Journal of India, 1996, 9(4): 156-159.

7. Lloyd CB, ed., Growing Up Global: The Changing Transitions to Adulthood in Developing Countries, Washington, DC: National Academies Press, 2005.

8. Gerard JM and Buehler C, Cumulative environmental risk and youth maladjustment: the role of youth attributes, 2004, Child Development, 75(6):1832-1849.

9. Jessor R, Adolescence as a critical life stage, paper presented at the WHO/UNICEF Adolescence Consultative Meeting, Washington, DC, June 12-16, 2000

10. Kirby D, Antecedents of adolescent initiation of sex, contraceptive use, and pregnancy, American Journal of Health Behavior, 2002, 26(6): $473-485$

11. Serovich J and Green K, Predictors of adolescent sexual risk taking behaviors which put them at risk for contracting HIV, Journal of Youth and Adolescence, 1997, 26(4):429-444.

12. Mott $F$ et al., The determinants of first sex by age 14 in a high-risk adolescent population, Family Planning Perspectives, 1996, 28(1):13-18.

13. Holtzman D and Rubinson R, Parent and peer communication effects on AIDS-related behavior among U.S. high school students, Family Planning Perspectives, 1995, 27(6):235-240.

14. Romer D et al., Social influences on the sexual behavior of youth at risk for HIV exposure, American Journal of Public Health, 1994, 84(6): 977-985

15. Crosby RA et al., Social capital as a predictor of adolescents' sexual risk behavior: a state-level exploratory study, AIDS and Behavior, 2003, $7(3): 245-252$.

16. McLanahan S and Bumpass L, Intergenerational consequences of family disruption, American Journal of Sociology, 1988, 94(1):130-152.

17. Newcomer S and Udry JR, Parental marital status effects on adolescents' sexual behavior, Journal of Marriage and the Family, 1987, 49(2): 235-240

18. Government of Maharashtra State, Economic Survey of Maharashtra 2005-06: selected socioeconomic indicators of states in India, <http://www.maharashtra.gov.in>, accessed Sept. 3, 2006.

19. International Institute for Population Sciences (IIPS) and ORC Macro, National Family Health Survey (NFHS-2), 1998-1999, India: Maharashtra, Mumbai: IIPS, 2002.

20. IIPS and Macro International, National Family Health Survey (NFHS3), 2005-2006: Vol. 1, Mumbai: IIPS, 2007.

21. National AIDS Control Organization (NACO), National AIDS Prevention and Control Policy, New Delhi: NACO, 2002.

22. Pune Municipal Corporation, Environmental Status Report 2001-2002, Pune, India: Pune Municipal Corporation, 2002.

23. Registrar General of India, Slum population, Series 1, Vol. 1, Census of India 2001, New Delhi: Office of the Registrar General of India and Census Commissioner, 2005, p. 212.

24. Alexander ML et al., Formation of Partnerships Among Young Women and Men: Findings from a Community-Based Study in Pune District, Maharashtra, New Delhi: Population Council, 2006.

25. Alexander ML et al., Romance and sex: pre-marital partnership formation among young women and men, Pune District, India, 2006, Reproductive Health Matters, 14(28):144-155.

26. Wellings K et al., Sexual behavior in context: a global perspective, Lancet, 2006, 368(9548):1706-1728.

27. Cleland J, Illustrative questionnaire for interview-surveys with young people, in: Cleland J, Ingham R and Stone N, eds., Asking Young People About Sexual and Reproductive Behaviors. Illustrative Core Instruments, Geneva: World Health Organization, 2001

28. Ganatra B, Abortion in rural Maharashtra, unpublished survey questionnaire, Pune: KEM Hospital Research Centre, 1995.

29. IIPS and Population Council, First time parents project: baseline survey, unpublished survey questionnaire, New Delhi: Population Council, 2002.

30. Patel V, Adolescents in Goa, unpublished survey questionnaire, Goa, India: Sangath, 2002.

31. Sebastian M et al., Integrating adolescent livelihood activities within a reproductive health program for urban slum dwellers in India, unpublished survey questionnaire, New Delhi: Population Council, 2004. 


\section{RESUMEN}

Contexto: Aunque las uniones premaritales-ya sea que involucren o no relaciones sexuales-son ampliamente desalentadas en la India, algunos jóvenes síforman ese tipo de uniones. Es importante saber más acerca de la naturaleza de este tipo de relación y de los factores asociados con ella.

Métodos: Los datos se han obtenido de un estudio basado en la comunidad, aplicado a personas entre 15 y 24 años en un barrio bajo urbano y en entornos rurales en el Distrito de Pune, Maharashtra. Se condujo una serie de análisis multivariados para identificar las asociaciones entre los individuos jóvenes, sus pares y sus familias, y sus experiencias en relaciones románticas e intimidad física, incluyendo la relación sexual.

Resultados: Entre los hombres jóvenes, 17-24\% habian tenido una relación romántica, 20-26\% habían participado en alguna forma de intimidad física y 16-18\% habían tenido relaciones sexuales; las proporciones entre las mujeres jóvenes fueron 5-8\%, 4-6\% y 1-2\%, respectivamente. La exposición al alcohol, drogas o filmes pornográficos, así como el tener una fuerte influencia de la red de pares, estuvieron asociados positivamente con las relaciones románticas y sexuales, tanto para las mujeres jóvenes como para los hombres jóvenes. Los logros educativos estuvieron asociados negativamente con ambos tipos de relaciones para las mujeres jóvenes, pero solamente con las relaciones sexuales para los hombres jóvenes. La cercanía con los padres estuvo asociada negativamente con formar parejas solamente para las mujeres jóvenes. Las mujeres jóvenes cuyo padre golpeaba a su madre tuvieron más probabilidad que otras mujeres jóvenes de formar parejas románticas; y aquellas golpeadas por sus familiares tuvieron un alto riesgo de formar uniones románticas y sexuales. Las personas jóvenes que reportaron tener una estricta supervisión de sus padres no tuvieron menor probabilidad que otras de formar relaciones.

Conclusiones: Las intervenciones programáticas deben garantizar que las personas jóvenes estén plenamente informadas y equipadas para elegir en forma segura y negociar los resultados deseados, mientras que influencian de manera positiva a sus redes de pares; alentar una mayor interacción entre padres e hijos; y estar diseñadas de acuerdo con las diferentes circunstancias y experiencias de las mujeres y hombres jóvenes.

\section{RÉSUMÉ}

Contexte: Bien que découragées, les relations prénuptialesavec rapports sexuels ou non-attirent certains jeunes en Inde. Il importe d'éclaircir davantage la nature de ces relations et les facteurs qui y sont associés.

Méthodes: Les données proviennent d'une étude communautaire des jeunes de 15 à 24 ans dans les bidonvilles et les milieux ruraux du district de Pune, au Maharashtra. Des analyses multivariées ont servi à identifier les associations entre les facteurs individuels, d'influence des pairs et familiaux des jeunes et leur expérience des relations romantiques et de l'intimité physique, y compris sexuelle.

Résultats: Parmi les jeunes hommes, 17\% à 24\% avaient eu une relation romantique, $20 \%$ à $26 \%$ s'étaient engagés dans une forme d'intimité physique et 16\% à 18\% avaient eu des rapports sexuels. Chez les jeunes femmes, ces proportions atteignent, respectivement, $5 \%$ à $8 \%, 4 \%$ à $6 \%$ et $1 \%$ à $2 \%$. L'exposition à l'alcool, à la drogue ou aux films pornographiques et la fréquence des rapports avec les pairs présentent une association positive avec les relations romantiques et sexuelles chez les jeunes, hommes et femmes. Le niveau de scolarité présente une association négative avec les deux types de relations chez les jeunes femmes, mais seulement avec celles de nature sexuelle chez les jeunes hommes. La proximité affective des parents est négativement associée à l'existence de relations côté féminin seulement. Les jeunes femmes dont le père battait la mère sont apparues plus susceptibles que les autres de participer à des relations romantiques, et celles battues par leur famille courent un risque élevé de relations romantiques et sexuelles. Les jeunes ayant déclaré une stricte surveillance parentale ne sont pas moins susceptibles que les autres de s'engager dans ces relations.

Conclusions: Les programmes d'intervention doivent assurer que les jeunes soient pleinement informés et équipés pour opérer des choix dénués de risque et négocier les issues désirées, tout en influençant positivement leurs réseaux de pairs. Ils doivent encourager des relations plus proches entre parents et enfants et s'adapter aux différentes circonstances et expériences des jeunes hommes et femmes.

\section{Acknowledgments}

This project was funded by a grant to the Population Council from the MacArthur Foundation, whose support is gratefully acknowledged. The authors thank Rajib Acharya, John Cleland, Deepika Ganju, KG Santhya, Lea Hegg and Leela Visaria for valuable comments; Mahesh Naik, for software development; Aparna Godke, Komal Saxena, Varsha Tol, Dipak Zade for support and assistance; the CASP coordinators for field support; and our team of young interviewers for their sensitive efforts at eliciting information.

Author contact: sjejeebhoy@popcouncil.org 